\title{
Analisa Indeks Kinerja Daerah Irigasi Taposan Kecamatan Dringu Kabupaten Probolinggo Menggunakan Software PDSDA-PAI
}

\author{
Lendi Dwi Pranoto $^{1 *}$, Sri Wahyuni ${ }^{1}$, Rahmah Dara Lufira ${ }^{1}$ \\ ${ }^{1}$ Jurusan Teknik Pengairan Universitas Brawijaya \\ Jalan Mayjen Haryono No. 167, Malang, 65145, Indonesia \\ *korespondasi email: dwilendy @gmail.com
}

\begin{abstract}
Probolinggo Regency is one of the national shallot barns in the East Java region (37\%), one of the areas in Probolinggo Regency that contributes to this is the Taposan Irrigation Area located in Dringu District, where its authority is under the UPT SDA Probolinggo Regency. One of the efforts to maintain shallot productivity is by carrying out maintenance and rehabilitation activities in the Taposan Irrigation Area, therefore the large system performance index value is needed to maintain and increase productivity in stabilizing the performance index value of the existing irrigation system. To calculate the system performance index in the Taposan Irrigation Area, an assessment of irrigation assets was carried out using the assessment method in PerMen PUPR No 12 / PRT / M / 2015, and also assisted by using the PDSDA-PAI Version 2.0 software. From the two methods used, the performance index results were $68.43 \%$ from the Blank method and $65.22 \%$ from the PDSDA-PAI software method, so it was concluded that the conditions of the Taposan irrigation area were still quite good with a Performance Index of $65 \%$. Furthermore, with the existing conditions only routine maintenance is required.
\end{abstract}

Keywords : PDSDA-PAI, Irrigation performance, priority scale of handling, irrigation assets.

Abstrak : Kabupaten Probolinggo merupakan salah satu lumbung
bawang merah nasional di wilayah Jawa Timur (37\%), salah satu
wilayah Di Kabupaten Probolinggo yang ikut berkontribusi akan hal
tersebut adalah Daerah Irigasi Taposan yang terletak di Kecamatan
Dringu, dimana kewenangannya berada di bawah UPT SDA Kabupaten
Probolinggo. Salah satu upaya untuk menjaga produktivitas bawang
merah adalah dengan melakukan kegiatan pemeliharaan dan rehabilitasi
pada Daerah Irigasi Taposan, oleh karena itu besarnya nilai indeks
kinerja sistem sangat diperlukan untuk menjaga serta meningkatkan 
produktivitas dalam menstabilkan nilai indeks kinerja sistem irigasi yang ada. Untuk memperhitungkan besarnya indeks kinerja sistem pada Daerah Irigasi Taposan dilakukan penilaian pada aset irigasi dengan menggunakan metode penilaian pada PerMen PUPR No 12/PRT/M/2015, dan juga dibantu dengan menggunakan software PDSDA-PAI Versi 2.0. Dari kedua metode yang digunakan didapatkan hasil Indeks Kinerja sebesar 68,43\% dari metode Blangko dan 65,22\% dari metode software PDSDA-PAI, sehingga disimpulkan kondisi dari Daerah irigasi Taposan terbilang masih cukup bagus dengan Indeks Kinerja 65\%. Selanjutnya dengan kondisi yang ada hanya diperlukan pemeliharaan secara rutin.

Kata kunci: Aset irigasi, Kinerja irigasi, PDSDA-PAI, Skala prioritas penanganan

\section{Pendahuluan}

Jawa timur menjadi daerah luas panen tanaman bawang merah terluas kedua sebesar 30.785 Ha setelah Jawa Tengah sebesar 42.628 Ha. Kabupaten yang menjadi pemasok utama tanaman bawang merah di Jawa Timur adalah Kabupaten Nganjuk dan Probolinggo. Data Badan Pusat Statistik kabupaten Probolinggo tahun 2015 menunjukkan kecamatan Dringu sebagai penghasil bawang merah terbanyak sebesar 34.689 ton [1].

Berdasarkan PerMen PUPR No. 14/PRT/M/2015 irigasi dapat diartikan sebagai usaha pengelolaan air irigasi termasuk diantaranya penyediaan, pengaturan, dan pembuangan guna menunjang pertanian [2]. Sedangkan jaringan irigasi diartikan sebagai serangkaian saluran dan bangunan beserta bangunan pelengkapnya untuk menyediaankan, membagikan, memberikan, menggunakan, dan membuang air irigasi . Menurut kelengkapan fasilitasnya, jaringan irigasi dibagi menjadi tiga sistem yaitu sistem irigasi teknis, semi teknis, dan sederhana.

Daerah Irigasi Taposan terletak di Desa Ngepoh, Kecamatan Dringu, Kabupaten Probolinggo. Data baku sawah Pengamat Pengairan Problinggo menunjukkan semua layanan Daerah Irigasi taposan masuk dalam wilayah Kecamatan Dringu. Berdasarkan data tersebut, perlu mempertahankan dan mengoptimalkan irigasi untuk meningkatkan potensi wilayah Kecamatan Dringu khususnya produksi bawang merah adalah rangka mencapai kedaulatan pangan. Pemerintah menyatakan pelaksanaan rehabilitasi kerusakan infrastruktur irigasi dilaksanakan dengan pengelolaan aset irigasi (manajemen aset). Penerepan manajemen aset dalam penelitian ini bertujuan untuk mengidentifikasi dan menganalisis kondisi dan fungsi aset irigasi Daerah Irigasi Taposan dalam menentapkan prioritas pemeliharaan aset irigasi Daerah Irigasi Taposan.

Dana menjadi salah satu faktor penting dalam merealisasikan pengembangan prasarana irigasi. setiap tahunnya dana yang diajukan guna pengelolaan jaringan irigasi tidak selalu terpenuhi dibandingkan dengan dana yang dibutuhkan. Oleh sebab itu dibutuhkan penyelesaian masalah berupa penentuan prioritas perbaikan aset irigasi agar dapat dilakukannya penanganan dengan mempertimbangkan ketersediaan dana yang diturunkan dan faktor lainnya.

Seiring rusaknya aset irigasi juga berdampak pada penurunan kondisi dan fungsi aset irigasi. Pemeliharaan dan rehabilitasi merupakan salah satu jawaban dari sekian pilihan untuk permasalahan yang ada, sehingga untuk menentukan tingkat kelayakan dibutuhkan standar nilai indeks kinerja sistem irigasi yang tinggi. Hal itu sekaligus menjawab terkait penurunan nilai indeks kinerja yang sudah ada. Selanjutnya untuk 
mempermudah dan menjaga hasil perhitungan nilai indeks kinerja Daerah Irigasi tetap dalam batas yg dikehendaki, penulis menambahkan penggunaan aplikasi Pengolah Data PAI v2.0 dalam studi ini.

Pengelolaan jaringan irigasi meliputi berbagai hal mulai dari operasi, pemeliharaan, hingga rehabilitasi jaringan irigasi di daerah irigasi. Kegiatan rehabilitasi termasuk dalam pelaksanaan dari pemeliharaan yang diatur dalam Pedoman Pemeliharaan Jaringan Irigasi yang dikeluarkan oleh pemerintah. Oleh karena itu pengelolaan irigasi hanya meliputi kegiatan operasi dan pemeliharaan.

Tujuan dilakukannya pemeliharaan Irigasi adalah untuk memnatau, menjaga dan mengamankan jaringan irigasi selalu berfungsi dengan baik melalui kegiatan perawatan, perbaikan, pencegahan dan pengamanan secara terus menerus. Jenis pemeliharaan jaringan irigasi terdiri dari perbaikan darurat, pemeliharaan rutin, pemeliharaan berkala, dan pengamanan jaringan irigasi.

Menurut PerMen PUPR No. 12/PRT/M/2015 terdapat 6 aspek yang perlu dievaluasi guna mengetahui kondisi kinerja sistem irigasi [3] antara lain :

1. Kondisi dari prasarana fisik,

2. Produktivitas tanam,

3. Sarana penunjang,

4. Organisasi personalia,

5. Dokumentasi, dan

6. Kondisi kelembagaan P3A.

Overseas Development Administration (1995:6) memaparkan tentang pelaksanaan menejemen asetnya yang dilakukan melalui beberapa tahap antara lain: klasifikasi daerah irigasi, identifikasi sistem kemampuan aset, estimasi biaya aset, peninjauan aset, dan menerapkan Perencanaan Manajemen Aset (PMA) [4]. Dalam peninjauan aset tersebut dilakukan penentuan prioritas aset, maka perlu dilakukan tindak lanjut, berdasarkan kondisi dan fungsi aset irigasi di lapangan saat ini kondisi dan fungsi aset irigasi yang telah terdata tersebut kemudian diinterpretasikan dalam Asset Survey.

\section{Bahan dan Metode}

2.1 Lokasi Studi

Pemilihan lokasi oleh penulis dalam studi ini terletak di sebuah desa di Kabupaten Probolinggo, tepatnya desa Ngepoh, kecamatan Dringu dengan Daerah Irigasi Taposan sebagai daerah studi yang akan dikaji. Dilihat dari letak geografis Kabupaten probolinggo berada pada koordinat $112^{\circ} 50^{\prime}-113^{\circ} 30^{\prime}$ BT dan $7^{\circ} 4^{\prime}-8^{\circ} 10^{\prime}$ LS. Kondisi wilayah Kecamatan Dringu sendiri terbilang relatif datar dan luas wilayahnya sendiri mencapai $36,86 \mathrm{~km}^{2}$ atau kurang lebih 1,84 persen dari total luas Kabupaten Probolinggo. Lokasi Kecamatan Dringu terletak di barat ibu kota Kabupaten Probolinggo dan batas-batas wilayahnya adalah sebagai berikut :

Utara : Selat Madura

Barat : Kota Probolinggo

Selatan : Leces dan Tegalsiwalan

Timur : Gending dan Banyuanyar

Sebagian besar penduduk di kecamatan Dringu bermatapencaharian sebagai buruh tani. Kecamatan Dringu sendiri terbagi menjadi 14 desa, dengan lebih dari 60\% luas wilayahnya merupakan lahan persawahan atau mencapai $1.880 \mathrm{Ha}$ dari 3.113,58 Ha luas total wilayah Kecamatan Dringu.

\subsection{Bahan}


Data-data yang dibutuhkan untuk melakukan analisis dalam studi kali ini adalah sebagai berikut:

1. Data Ketersediaan Air

2. Data Statis dan Dinamis

3. Data Luas Tanam

4. Data Aset pendukung

5. Data Peta Skema Konstruksi dan Eksploitasi

\subsection{Metode}

2.3.1. Analisa Debit Andalan Metode Modus-Median

Analisa Debit Andalan menggunakan data pencatatan debit yang masuk ke dalam intake periode 10 harian mulai tahun 2008-2017. Metode yang dipergunakan adalah metode Modus dan Median.

$$
M_{d}=b+i\left(\frac{k_{1}-F}{f}\right)
$$

Pers. 1

$$
\begin{array}{cl}
\text { dengan: } & \\
M_{d} & =\text { Median } \\
b & =\text { tepi bawah } \\
i & =\text { interval kelas } \\
k_{1} & =\text { letak median } \\
\mathrm{F} & =\text { frekuensi kumulatif sebelum kelas median } \\
\mathrm{f} & =\text { frekuensi kelas median } \\
M_{o}=B+i\left(\frac{f-f_{1}}{\left(f-f_{1}\right)+\left(f-f_{2}\right)}\right) \\
\text { dengan: } & \\
M_{o} & =\text { Modus } \\
\mathrm{B} & =\text { batas bawah interval kelas modus } \\
i & =\text { interval kelas } \\
\mathrm{f} & =\text { frekuensi maksimum modus } \\
\mathrm{f}_{1} & =\text { frekuensi sebelum kelas modus } \\
\mathrm{f}_{2} & =\text { frekuensi setelah kelas modus }
\end{array}
$$

\subsubsection{Evaluasi Kebutuhan Air Nyata}

Agar air dapat dimanfaatkan secara efektif perlu adanya penyesuaian pola tanam untuk memperoleh luas tanam yang optimal. Karena kebutuhan air irigasi ditentukan oleh pola tanam dan jenis tanaman. Pada lokasi penelitian pola tanam yang diterapkan petani adalah Padi+Palawija+Palawija dengan awal tanam pada bulan November.

\subsubsection{Neraca Air Kondisi Eksisting}

Neraca air merupakan hubungan antara ketersediaan dengan kebutuhan air yang diperlukan pada intake. Hubungan ini adalah salah satu dasar pengambilan keputusan pedoman kegiatan pemberian maupun pembagian air irigasi, kaitannya dengan pola tata tanam dan tata guna air irigasi.

\subsubsection{Pengelolaan Data dengan Perangkat Lunak Komputer}

- Tahapan pertama, tahapan pengolahan data GPS. Software yang digunakan dalam proses pengolahan data GPS pada studi ini adalah MapSource v.6.13.7.

- Tahapan kedua, proses konversi data GPS dengan menggunakan software Global Mapper. 
- Tahapan ketiga, proses pengolahan data tracks dan waypoints dengan menggunakan AutoCAD

- Tahapan keempat, mengulangi proses konversi data dengan menggunakan Software Global Mapper dikonversi ke dalam format Shapefile (.shf)

- Tahapan kelima adalah pengisian data pada software PDSDA-PAI Versi 2.0.

2.3.5. Perhitungan kinerja jaringan irigasi dengan menggunakan blangko dan software PDSDA-PAI

Kinerja jaringan irigasi dihitung secara langsung dari hasil penelusuran jaringan irigasi Taposan yang dilakukan pada tahun 2018. Proses Inventarisasi pada studi ini dilakukan secara partisipatif dengan cara penelusuran jaringan irigasi langsung oleh aparat dinas bersama perkumpulan petani pemakai air (P3A) memakai Blangko Invetarisasi pada lampiran Peranturan Menteri PU no. 23/PRT/M/2015.

\subsubsection{Analisa Statistik}

Analisa statistik digunakan sebagai alat untuk mengetahui sebab akibat antara dua atau lebih variabel, menyimpulkan suatu perbedaan yang didapatkan apakah berbeda secara signifikan atau tidak. Analisa statistik juga dapat digunakan sebagai penguji hipotesis untuk mengambil keputusan apakah menerima atau menolak hipotesis.

$$
H=\frac{12}{N(N+1)} \sum_{K=1}^{K} \frac{R_{K}^{2}}{n_{K}}-3(N+1)
$$

dengan:

$$
\begin{array}{ll}
\mathrm{H} & \text { = Kruskal-Wallis } \\
\mathrm{N} & \text { = Jumlah pengamatan di semua kelompok } \\
\mathrm{K} & \text { = Jumlah kelompok } \\
\mathrm{R} & \text { = Jumlah ranking } \\
\mathrm{n} & \text { = Jumlah pengamatan dalam kelompok }
\end{array}
$$

\subsubsection{Skala Prioritas Penanganan Berdasarkan Bobot Nilai kondisi Fisik}

Penentuan skala prioritas penanganan Daerah Irigasi Taposan didasarkan pada

\begin{tabular}{|c|c|c|c|c|c|c|c|}
\hline $\begin{array}{l}\text { Bulan } \\
\text { Tahun }\end{array}$ & Periode & $\begin{array}{c}\text { Rata- } \\
\text { rata }\end{array}$ & Max & Min & Interval & Median & Modus \\
\hline \multirow{4}{*}{ Jan } & I & 2948 & 1130 & 627 & 126 & $\begin{array}{l}1017,6 \\
19\end{array}$ & 1052 \\
\hline & II & 1104 & 1573 & 528 & 261 & 1148 & 1137 \\
\hline & III & 1073 & 1429 & 606 & 206 & 1095,1 & 1121 \\
\hline & I & 1179 & 1680 & 626 & 263 & 1251,8 & 1285 \\
\hline \multirow[t]{3}{*}{ Feb } & II & 1246 & 1776 & 634 & 286 & 1312,1 & 1348 \\
\hline & III & 1248 & 1646 & 706 & 235 & 1434,5 & 1515 \\
\hline & I & 1304 & 1667 & 775 & 223 & 1332,5 & 1317 \\
\hline \multirow[t]{3}{*}{ Mar } & II & 1210 & 1504 & 818 & 171 & 1289,6 & 1218 \\
\hline & III & 1221 & 1514 & 882 & 158 & 1224,3 & 1317 \\
\hline & I & 1178 & 1448 & 793 & 164 & 1242,7 & 1175 \\
\hline \multirow[t]{3}{*}{ Apr } & II & 1101 & 1436 & 775 & 165 & 1133,6 & 1106 \\
\hline & III & 1062 & 1626 & 721 & 226 & 1060,1 & 1012 \\
\hline & I & 936 & 1213 & 659 & 139 & 959,1 & 936 \\
\hline \multirow[t]{2}{*}{ Mei } & II & 916 & 1167 & 549 & 155 & 966,2 & 968 \\
\hline & III & 797 & 1059 & 552 & 127 & 767,7 & 727 \\
\hline Jun & I & 729 & 953 & 332 & 155 & 778 & 642 \\
\hline
\end{tabular}
besarnya Nilai Kondisi Fisik (NKF) tiap aspek dan sub-aspek pada perhitungan Penilaian Kinerja Sistem Irigasi dari pengolahan data sebelumnya

\section{Hasil dan Pembahasan}

3.1. Analisa Debit Andalan Metode Modus-Median

Tabel 1. Perhitungan Debit Andalan 


\begin{tabular}{lccccccc}
\hline & II & 615 & 845 & 313 & 133 & 725,3 & 771 \\
& III & 615 & 899 & 301 & 149 & 674,7 & 664 \\
& I & 557 & 822 & 226 & 149 & 598,5 & 588 \\
\multirow{3}{*}{ Jul } & II & 578 & 856 & 262 & 148 & 534,6 & 470 \\
& III & 567 & 797 & 262 & 134 & 630,3 & 575 \\
\hline
\end{tabular}

\section{Lanjutan Tabel 1. Perhitungan Debit Andalan}

\begin{tabular}{cccccccc}
\hline Bulan & Periode & $\begin{array}{c}\text { Rata- } \\
\text { rata }\end{array}$ & Max & Min & Interval & Median & Modus \\
& I & 583 & 932 & 257 & 169 & 636,2 & 636 \\
Agust & II & 584 & 873 & 258 & 154 & 604,4 & 604 \\
& III & 530 & 768 & 245 & 131 & 572,3 & 563 \\
& I & 514 & 773 & 221 & 138 & 566 & 556 \\
Sept & II & 542 & 789 & 321 & 117 & 535,5 & 497 \\
& III & 541 & 846 & 301 & 136 & 505,1 & 513 \\
& I & 585 & 1032 & 307 & 181 & 473,1 & 398 \\
Okt & II & 613 & 1110 & 334 & 194 & 511,7 & 431 \\
& III & 650 & 1168 & 328 & 210 & 520,6 & 433 \\
& I & 644 & 1065 & 335 & 183 & 654 & 639 \\
Nov & II & 739 & 1287 & 341 & 236 & 743,5 & 679 \\
& III & 790 & 1131 & 341 & 198 & 834,8 & 736 \\
& I & 843 & 1119 & 454 & 166 & 869,1 & 786 \\
Des & II & 865 & 1190 & 496 & 174 & 825,2 & 756 \\
& III & 912 & 1164 & 624 & 135 & 910,9 & 975 \\
\hline \multirow{6}{*}{ Sumber: Hasil Perhitungan $(2020)$} &
\end{tabular}

3.2. Evaluasi Kebutuhan Air Nyata

Tabel 2. Kriteria LPR Tanaman Lokasi Studi

\begin{tabular}{|c|c|c|c|c|c|c|c|c|}
\hline \multirow{2}{*}{ 责 } & \multirow[t]{2}{*}{ Keterangan } & \multirow{2}{*}{$\begin{array}{c}\text { Luas } \\
\text { Tanam } \\
\text { Rerata } \\
(\mathrm{Ha}) \\
\end{array}$} & \multicolumn{2}{|c|}{$\begin{array}{l}\text { Kebutuhan Air } \\
\text { Rerata }\end{array}$} & \multirow[t]{2}{*}{ FPR } & \multicolumn{3}{|c|}{$\begin{array}{c}\text { Koefisien pembanding LPR } \\
\text { Tanaman }\end{array}$} \\
\hline & & & $(\mathrm{lt} / \mathrm{dt})$ & (lt/dt/ha) & & \multicolumn{2}{|c|}{ Lokasi Studi } & Pedoman \\
\hline \multirow{4}{*}{ I } & Padi Bibit & 38,83 & 457,90 & $\begin{array}{l}17781,9 \\
\end{array}$ & \multirow{4}{*}{0,587} & 20,088 & Padi Bibit & Padi Bibit \\
\hline & Padi Garap & 34,77 & 122,86 & 4272,0 & & 6,020 & 19,579 & 20 \\
\hline & Padi Tanam & 28,83 & 70,58 & 2035,0 & & 4,170 & & \\
\hline & Palawija & 285,23 & 168,42 & 48037,5 & & 1,006 & Padi C & Padi Garap \\
\hline \multirow{4}{*}{ II } & Padi Bibit & 41,48 & 488,91 & 20282,2 & \multirow{4}{*}{0,618} & 19,070 & 5,753 & 6 \\
\hline & Padi Garap & 30,23 & 106,55 & 3220,9 & & 5,703 & & \\
\hline & Padi Tanam & 40,06 & 100,41 & 4022,7 & & 4,056 & Padi Tanam & Padi Tanam \\
\hline & Palawi & 428,56 & 258,25 & 110678,1 & & 0,975 & 3,854 & 4 \\
\hline \multirow{4}{*}{ III } & Padi Bibit & 0,00 & 0,00 & 0,0 & \multirow{4}{*}{0,582} & - & & \\
\hline & Padi Garap & 3,00 & 9,67 & 29,0 & & 5,536 & Palawija & Palawija \\
\hline & Padi Tanam & 15,86 & 30,81 & 488,7 & & 3,337 & 0,995 & 1 \\
\hline & Palawija & 585,03 & 341,97 & 200062,8 & & 1,004 & & \\
\hline
\end{tabular}

Sumber: Hasil Perhitungan (2020)

3.3. Neraca Air Kondisi Eksisting

Tabel 3. Rerata Evaluasi Pembagian Air Irigasi Masa Tanam 2013-2017

\begin{tabular}{cccccc}
\hline Bulan & Periode & $\begin{array}{c}\text { Total Keb. Air } \\
\text { Irigasi } \\
(\mathrm{l} / \mathrm{dt})\end{array}$ & $\begin{array}{c}\text { Q andalan } \\
(\mathrm{l} / \mathrm{dt})\end{array}$ & \multicolumn{2}{c}{ Evaluasi Pembagian Air } \\
Faktor K & Kriteria Faktor K \\
\hline \hline & I & 357 & 639 & 1,791 & Terus - menerus \\
Nov & II & 531 & 679 & 1,279 & Terus - menerus \\
& III & 661 & 736 & 1,114 & Terus - menerus \\
Des & I & 711 & 786 & 1,105 & Terus - menerus \\
\hline
\end{tabular}




\begin{tabular}{cccccc}
\hline & II & 751 & 756 & 1,006 & Terus - menerus \\
& III & 829 & 975 & 1,176 & Terus - menerus \\
& I & 926 & 1052 & 1,136 & Terus - menerus \\
\multirow{3}{*}{ Jan } & II & 1383 & 1137 & 0,822 & Terus - menerus \\
& III & 1429 & 1121 & 0,784 & Terus - menerus \\
\hline
\end{tabular}

Lanjutan Tabel 3. Rerata Evaluasi Pembagian Air Irigasi Masa Tanam 2013-2017

\begin{tabular}{|c|c|c|c|c|c|}
\hline \multirow{2}{*}{ Bulan } & \multirow{2}{*}{ Periode } & \multirow{2}{*}{$\begin{array}{c}\text { Total Keb. Air } \\
\text { Irigasi } \\
(1 / d t)\end{array}$} & \multirow{2}{*}{$\begin{array}{c}\text { Q andalan } \\
(1 / d t)\end{array}$} & \multicolumn{2}{|c|}{ Evaluasi Pembagian Air } \\
\hline & & & & Faktor K & Kriteria Faktor K \\
\hline \multirow{3}{*}{ Feb } & $\overline{\mathrm{II}}$ & 1512 & 1285 & 0,850 & Terus - menerus \\
\hline & II & 1572 & 1348 & 0,858 & Terus - menerus \\
\hline & III & 1488 & 1515 & 1,018 & Terus - menerus \\
\hline \multirow{3}{*}{ Mar } & I & 1488 & 1317 & 0,885 & Terus - menerus \\
\hline & II & 1335 & 1218 & 0,913 & Terus - menerus \\
\hline & III & 1084 & 1317 & 1,215 & Terus - menerus \\
\hline \multirow{3}{*}{ Apr } & I & 793 & 1175 & 1,481 & Terus - menerus \\
\hline & II & 880 & 1106 & 1,257 & Terus - menerus \\
\hline & III & 764 & 1012 & 1,324 & Terus - menerus \\
\hline \multirow{3}{*}{ Mei } & $\mathrm{I}$ & 688 & 936 & 1,361 & Terus - menerus \\
\hline & II & 609 & 968 & 1,591 & Terus - menerus \\
\hline & III & 555 & 727 & 1,309 & Terus - menerus \\
\hline \multirow{3}{*}{ Jun } & I & 332 & 642 & 1,933 & Terus - menerus \\
\hline & II & 374 & 771 & 2,062 & Terus - menerus \\
\hline & III & 393 & 664 & 1,689 & Terus - menerus \\
\hline \multirow{3}{*}{ Jul } & I & 393 & 588 & 1,495 & Terus - menerus \\
\hline & II & 379 & 470 & 1,242 & Terus - menerus \\
\hline & III & 330 & 575 & 1,740 & Terus - menerus \\
\hline \multirow{3}{*}{ Agust } & I & 326 & 636 & 1,951 & Terus - menerus \\
\hline & II & 355 & 604 & 1,702 & Terus - menerus \\
\hline & III & 316 & 563 & 1,781 & Terus - menerus \\
\hline \multirow{3}{*}{ Sept } & I & 316 & 556 & 1,761 & Terus - menerus \\
\hline & II & 352 & 497 & 1,410 & Terus - menerus \\
\hline & III & 316 & 513 & 1,624 & Terus - menerus \\
\hline \multirow{3}{*}{ Okt } & I & 316 & 398 & 1,259 & Terus - menerus \\
\hline & II & 377 & 431 & 1,144 & Terus - menerus \\
\hline & III & 383 & 433 & 1,131 & Terus - menerus \\
\hline
\end{tabular}

Sumber: Hasil Perhitungan (2020) 
Gambar 1 Grafik Neraca Air Eksisting 2013-2017

3.4. Perhitungan kinerja jaringan irigasi dengan menggunakan blangko dan software PDSDA-PAI

Tabel 4. Perbandingan Nilai Indeks Kinerja Daerah Irigasi Taposan

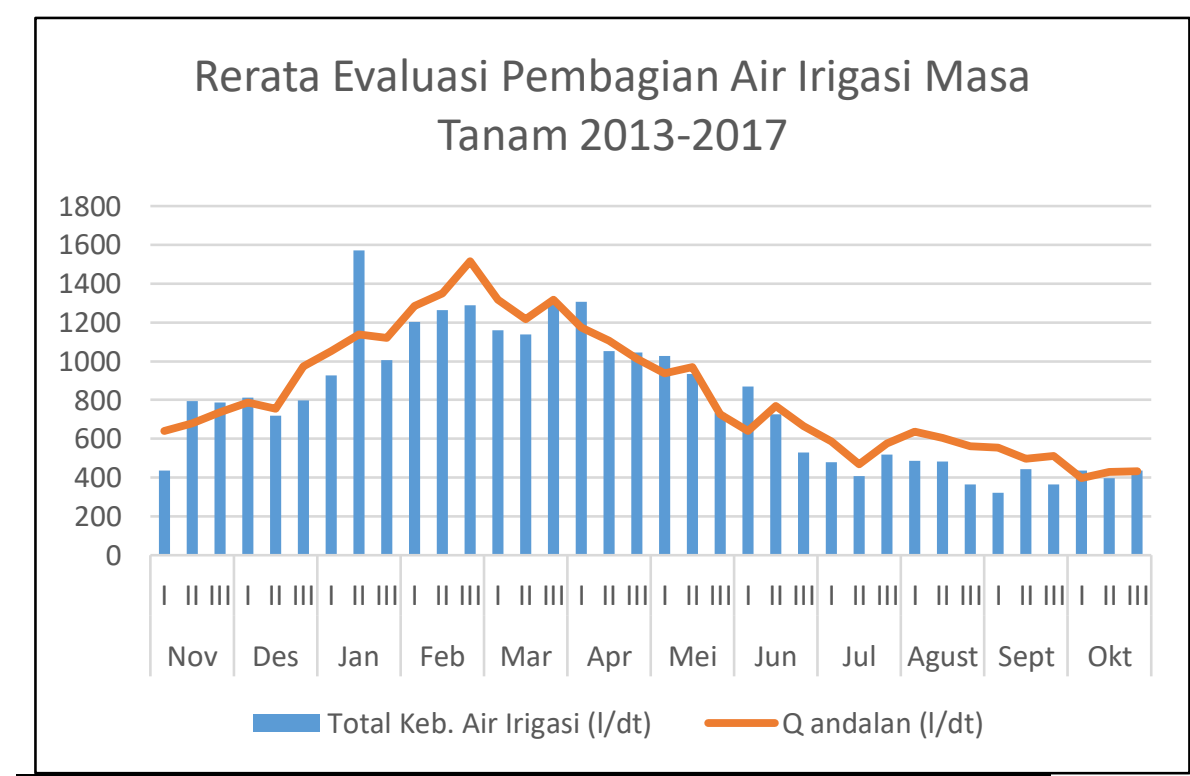

No Perihal $\begin{gathered}\text { Indeks Kinerja Saat Ini } \\ \text { Blangko }\end{gathered}$




\begin{tabular}{|c|c|c|c|}
\hline 1 & Kondisi Prasarana & 31,76 & 35,22 \\
\hline 2 & Ketersediaan Air & \multirow{2}{*}{13,34} & 6 \\
\hline 3 & Indeks Pertanaman & & 4 \\
\hline 4 & Sarana Penunjang & 6,83 & 5 \\
\hline 5 & Operasi Personalia & 9,00 & 7,5 \\
\hline 6 & Dokumentasi & 2,9 & 2,5 \\
\hline 7 & P3A & 4,6 & 5 \\
\hline & JUMLAH & 68,43 & 65,22 \\
\hline
\end{tabular}

3.5. Analisa Statistik

Tabel 5. Nilai Indeks Kinerja yang telah diurutkan

\begin{tabular}{clcccc}
\hline \multirow{2}{*}{ No } & \multicolumn{1}{c}{ Perihal } & \multicolumn{2}{c}{ Blangko } & \multicolumn{2}{c}{ Software PDSDA-PAI Versi 2.0 } \\
& & Nilai & No. Urut & Nilai & No. Urut \\
\hline 1 & Kondisi Prasarana & 31,76 & 12 & 35,22 & 13 \\
2 & Ketersediaan Air & & & 6 & 7 \\
3 & Indeks Pertanaman & 13,34 & 11 & 4 & 3 \\
4 & Sarana Penunjang & 6,83 & 8 & 5 & 5 \\
5 & Operasi Personalia & 9,00 & 10 & 7,5 & 9 \\
6 & Dokumentasi & 2,9 & 2 & 2,5 & 1 \\
7 & P3A & 4,6 & 4 & 5 & 6 \\
& JUMLAH & 68,43 & 47 & 65,22 & 44 \\
\hline
\end{tabular}

Sumber: Hasil Perhitungan (2020)

$$
\begin{aligned}
H & =\frac{12}{N(N+1)} \sum_{K=1}^{K} \frac{R_{K}^{2}}{n_{K}}-3(N+1) \\
& =\frac{12}{13(13+1)}\left(\frac{47^{2}}{6}+\frac{44^{2}}{7}\right)-3(13+1) \\
& =0,065934(644,7381)-42 \\
& =0,5102
\end{aligned}
$$

Hipotesa yang digunakan:

$\mathrm{H} 0$ diterima apabila : $\mathrm{H} \leq \mathrm{X} ; \mathrm{K}-1$

H0 ditolak apabila : $\mathrm{H}>\mathrm{X} ; \mathrm{K}-1$

$$
X_{\alpha ; k-1}=X_{0.05 ; 1}=3,84
$$

Hasil akhir dari Uji Kruskall-Wallis adalah $\mathrm{H}<\mathrm{X}$ jadi H0 diterima. Dan tidak perlu dilanjutkan ke uji Mann-whitney.

3.6. Skala Prioritas Penanganan Berdasarkan Bobot Nilai kondisi Fisik

Tabel 6. Nilai Kondisi Aspek Tiap Aset Dan Sup-Aspek

ASPEK NKF $\begin{gathered}\text { Urutan Prioritas } \\ \text { Penanganan }\end{gathered}$




\begin{tabular}{|c|c|c|c|}
\hline $\bar{I}$ & Prasarana Fisik & 67,58 & \\
\hline 1.1 & $\begin{array}{l}\text { Bangunan Utama yang ada bangunan kantong } \\
\text { Lumpur }\end{array}$ & 79,27 & 21 \\
\hline 1.2 & Saluran Pembawa & 71,5 & 15 \\
\hline 1.3 & Bangunan pada saluran pembawa & 74,46 & 19 \\
\hline 1.4 & Saluran Pemabawa dan Bangunannya & 67,5 & 13 \\
\hline 1.5 & Jalan masuk/ inspeksi & 73,75 & 18 \\
\hline 1.6 & kantor, Perumahan, dan Gudang & 39 & 3 \\
\hline II & Produktivitas Tanaman & 81,53 & \\
\hline 2.1 & Pemenuhan kebutuhan air (faktor K) & 100 & 24 \\
\hline 2.2 & Realisasi luas tanam & 72,50 & 17 \\
\hline 2.3 & Produktivitas Padi & 72,10 & 16 \\
\hline III & Sarana Penunjang & 71,47 & \\
\hline 3.1 & Peralatan O\&P & 55,63 & 7 \\
\hline 3.2 & Transportasi & 66,25 & 12 \\
\hline 3.3 & Alat-alat kantor Pelaksanaan OP & 85 & 23 \\
\hline 3.4 & Alat komunikasi & 79 & 20 \\
\hline IV & Operasi Personalia & 62,50 & \\
\hline 4.1 & $\begin{array}{l}\text { Organisasi O\&P telah disusun dengan } \\
\text { batasan-batasan tanggung jawab dan tugas } \\
\text { yang jelas. }\end{array}$ & 70 & 14 \\
\hline 4.2 & Personalia & 55 & 6 \\
\hline $\mathrm{V}$ & Dokumentasi & 56,67 & \\
\hline 5.1 & Buku Data DI & 50 & 5 \\
\hline 5.2 & Peta dan Gambar-gambar & 63,33 & 11 \\
\hline VI & P3A & 51,43 & \\
\hline 6.1 & GP3A/IP3A sudah berbadan hukum & 60 & 8 \\
\hline 6.2 & Kondisi kelembagaan GP3A/IP3A & 60 & 9 \\
\hline 6.3 & $\begin{array}{l}\text { Rapat Ulu Ulu/ P3A desa/ GP3A dengan } \\
\text { Pengamat/ Ranting/ UPTD }\end{array}$ & 40 & 4 \\
\hline 6.4 & $\begin{array}{l}\text { P3A aktif mengikuti survei/penelusuran } \\
\text { jaringan }\end{array}$ & 80 & 22 \\
\hline 6.5 & $\begin{array}{l}\text { partisipasi P3A dalam perbaikan jaringan dan } \\
\text { penanganan bencana alam }\end{array}$ & 30 & 1 \\
\hline 6.6 & $\begin{array}{l}\text { Iuran P3A digunakan untuk perbaikan } \\
\text { jaringan }\end{array}$ & 30 & 2 \\
\hline 6.7 & $\begin{array}{l}\text { Partisipasi P3A dalam perencanaan Tata } \\
\text { Tanam dan Pengalokasian Air }\end{array}$ & 60 & 10 \\
\hline
\end{tabular}

$$
\text { Sumber: Hasil Perhitungan (2020) }
$$

Tabel 7. Urutan Prioritas Penanganan Berdasarkan Tingkat Urgensi

\begin{tabular}{|c|c|c|c|c|}
\hline $\begin{array}{l}\text { No } \\
{[1]}\end{array}$ & $\begin{array}{l}\text { Aset } \\
{[2]}\end{array}$ & $\begin{array}{c}\text { nomenklatur } \\
{[3]}\end{array}$ & $\begin{array}{c}\text { Skor } \\
\text { prioritas } \\
{[4]}\end{array}$ & $\begin{array}{c}\text { Tingkat } \\
\text { Urgensi } \\
{[5]}\end{array}$ \\
\hline 1 & Saluran Sekunder Pembawa & S.TP 7 & 7,22 & UR \\
\hline 2 & Saluran Sekunder Pembawa & S.TP 1 & 8,24 & KU \\
\hline
\end{tabular}

Lanjutan Tabel 7. Urutan Prioritas Penanganan Berdasarkan Tingkat Urgensi

\begin{tabular}{|c|c|c|c|c|}
\hline $\begin{array}{l}\text { No } \\
\text { [1] }\end{array}$ & $\begin{array}{c}\text { Aset } \\
{[2]}\end{array}$ & $\begin{array}{c}\text { nomenklatur } \\
\text { [3] }\end{array}$ & $\begin{array}{c}\text { Skor } \\
\text { prioritas } \\
{[4]}\end{array}$ & $\begin{array}{c}\text { Tingkat } \\
\text { Urgensi } \\
{[5]}\end{array}$ \\
\hline 3 & Saluran Sekunder Pembawa & S.TP 2 & 9,96 & UR \\
\hline 4 & Saluran Sekunder Pembawa & S.TP 5 & 13,3 & UR \\
\hline
\end{tabular}




\begin{tabular}{|c|c|c|c|c|}
\hline 5 & Saluran Sekunder Pembawa & S.GYM 1 & 24,79 & UR \\
\hline 6 & Saluran Sekunder Pembawa & S.GYM 2 & 25,49 & UR \\
\hline 7 & Saluran Sekunder Pembawa & S.GYM 3 & 26,15 & UR \\
\hline 8 & Bangunan Ukur & B.TP 7 Kr 1a & & JP \\
\hline 9 & Jembatan Orang & B.TP $2 g$ & & JP \\
\hline 10 & Bangunan Ukur & B.TP 4 Kn 1a & & JP \\
\hline 11 & Bangunan Ukur & B.TP $7 \mathrm{Kn} \mathrm{1a}$ & & JP \\
\hline 12 & Bangunan Ukur & B.TP $5 \mathrm{Kr} 1 \mathrm{a}$ & & $\mathrm{JP}$ \\
\hline 13 & Tempat cuci & B.TP $1 \mathrm{~d}$ & & JP \\
\hline 14 & Bangunan Ukur & B.TP $3 \mathrm{Tg} 1 \mathrm{a}$ & & JP \\
\hline 15 & Tempat cuci & B.TP $1 \mathrm{Kn} 1 \mathrm{a}$ & & JP \\
\hline 16 & Bangunan Ukur & B.TP $1 \mathrm{Kn} 1 \mathrm{~b}$ & & JP \\
\hline 17 & Bangunan Ukur & B.TP $3 \mathrm{Kr} 1 \mathrm{a}$ & & JP \\
\hline 18 & Bangunan Ukur & B.TP 7 Tg 1a & & JP \\
\hline 19 & Saluran Sekunder Pembawa & S.TP 3 & & JP \\
\hline 20 & Sadap & B.TP 5 & & JP \\
\hline 21 & Bangunan Ukur & B.TP $2 \mathrm{Kr} 1 \mathrm{a}$ & & JP \\
\hline 22 & Tempat cuci & B.TP $2 \mathrm{c}$ & & JP \\
\hline 23 & Tempat cuci & B.TP $2 \mathrm{f}$ & & JP \\
\hline 24 & Tempat cuci & B.TP 2d & & JP \\
\hline 25 & Tempat cuci & B.TP $6 b$ & & JP \\
\hline 26 & Tempat cuci & B.TP 3a & & JP \\
\hline 27 & Tempat cuci & B.TP $2 b$ & & JP \\
\hline 28 & Tempat mandi hewan & B.TP $2 \mathrm{~h}$ & & JP \\
\hline 29 & Tempat cuci & B.TP $1 \mathrm{Kn} 1 \mathrm{~d}$ & & JP \\
\hline 30 & Tempat mandi hewan & B.TP 6d & & JP \\
\hline 31 & Jembatan Orang & B.TP 1a & & JP \\
\hline 32 & Tempat cuci & B.TP $1 \mathrm{Kn} \mathrm{1c}$ & & JP \\
\hline 33 & Bangunan Ukur & B.TP $6 \mathrm{Kr} 1 \mathrm{a}$ & & JP \\
\hline 34 & Sadap & B.TP 1 & & JP \\
\hline 35 & Tempat cuci & B.TP $2 \mathrm{a}$ & & JP \\
\hline 36 & Saluran Sekunder Pembawa & S.TP 10 & & $\mathrm{JP}$ \\
\hline 37 & Bangunan Akhir & GYM 3 & & JP \\
\hline 38 & Sadap & B.TP 3 & & JP \\
\hline 39 & Bangunan Akhir & B.TP $1 \mathrm{Kn} 1$ & & JP \\
\hline 40 & Pintu pembuang & GYM 3a & & JP \\
\hline 41 & Sadap & GYM 2 & & UR \\
\hline 42 & Sadap & B.TP 4 & & JP \\
\hline 43 & Sadap & B.TP 2 & & UR \\
\hline
\end{tabular}

Lanjutan Tabel 7. Urutan Prioritas Penanganan Berdasarkan Tingkat Urgensi

\begin{tabular}{rrlcc}
\hline No & Aset & nomenklatur & $\begin{array}{c}\text { Skor } \\
\text { prioritas }\end{array}$ & $\begin{array}{c}\text { Tingkat } \\
\text { Urgensi } \\
{[1]}\end{array}$ \\
\hline 44 & Sadap & {$[3]$} & {$[4]$} & {$[5]$} \\
45 & Sadap Langsung & GYM 1 & & UR \\
\hline
\end{tabular}




\begin{tabular}{lllc}
\hline 46 & Sadap Langsung & B.TP 6a & SU \\
47 & Sadap & B.TP 6 & JP \\
48 & Jembatan Desa & B.TP 3b & JP \\
49 & Bangunan Akhir & B.TP 7 & JP \\
50 & Sadap Langsung & B.TP 6c & UR \\
51 & Jembatan Desa & B.TP 1a & JP \\
52 & Saluran Sekunder Pembawa & S.TP 6 & JP \\
53 & Saluran Sekunder Pembawa & S.TP 9 & JP \\
54 & Bendung & B.TP 0 & JP \\
55 & Talang & B.TP 1c & JP \\
56 & Saluran Sekunder Pembawa & S.TP 8 & JP \\
57 & Saluran Sekunder Pembawa & S.TP 4 & JP \\
\hline
\end{tabular}

Sumber : Hasil Perhitungan (2020)

\section{Kesimpulan}

Dari serangkaian kegiatan penelitian yang telah dilakukan didapatkan beberapa kesimpulan antara lain :

- Secara umum kondisi aset Daerah Irigasi Taposan cukup baik.

- Dari beberapa aspek yang ada, prioritas penanganan pada Daerah Irigasi Taposan yaitu pembenahan pada aspek P3A $(51,43)$, aspek Dokumentasi $(56,67)$ dan Personalia $(62,50)$.

- Terdapat beberapa kekurangan pada aset irigasi, seperti terdapat banyak gerusan pada bagian hilir bangunan sadap, banyaknya vegetasi dan tumpukan sampah yang mengganggu aliran air bahkan menyumbat saluran, juga terkait sumber daya manusia sarana penunjang transportasi yang terbatas, selain itu masih jarang diadakannya pertemuan antara pihak pengelola dengan P3A.

- Terdapat selisih nilai indeks kinerja sebesar 3,21\%, dengan rincian metode blangko sebesar $68,43 \%$, dan metode software PDSDA-PAI sebesar 65,22\%. Selisih tersebut disebabkan oleh adanya perbedaan pada parameter kondisi dan penilaian kondisi dari kedua metode. Berdasarkan hasil penilaian indeks kinerja kedua metode, kondisi Daerah Irigasi Taposan dapat dikatakan dalam kondisi cukup baik dan hanya memerlukan pemeliharaan secara rutin

\section{Daftar Pustaka}

[1] Badan Pusat Statistik Kabupaten Probolinggo, 2015. Kabupaten Probolinggo Dalam Angka. Probolinggo: Pemerintah Kabupaten Probolinggo

[2] Menteri Pekerjaan Umum. 2015. Peraturan Menteri Pekerjaan Umum dan Perumahan Rakyat Republik Indonesia Nomor 14/PRT/M/2015 tentang Kriteria Dan Penetapan Status Daerah Irigasi. Jakarta: Menteri Pekerjaan Umum dan Perumahan Rakyat.

[3] Menteri Pekerjaan Umum. 2015. Peraturan Menteri Pekerjaan Umum dan Perumahan Rakyat Republik Indonesia Nomor 12/PRT/M/2015 tentang Eksploitasi Dan Pemeliharaan Jaringan Irigasi. Jakarta: Menteri Pekerjaan Umum dan Perumahan Rakyat. 
Pranoto, L. D. et al., Jurnal Teknologi dan Rekayasa Sumber Daya Air Vol. 1 No. 1 (2021) p. 252-263

[4] Overseas Development Administration. 1995. Asset Management Procedures for Irrigation Schemes. UK Institude of Irrigation Studies. University do Southampton 